\title{
PENGARUH WAKAF DALAM KEHIDUPAN EKONOMI
}

\author{
Oleh: \\ A. Taufiq Buhari ${ }^{1}$ \\ Email: taufiqbuhari@gmail.com
}

\begin{abstract}
Waqf has taken root and become a tradition of Muslims in various countries. Waqf is one of the main pillars of the development of Islamic society, because most of the houses of worship, Islamic schools and other Islamic religious institutions are built on waqf land. Waqf institutions which are sources of assets can provide benefits for all time. However, the productive collection, management and utilization of waqf assets in Indonesia is still small and lagging behind other countries. Likewise, the study of trust in Indonesia is still focused on the legal aspects of figh, and has not touched on the management of trust. Though waqf should be managed productively and produce results to the community, so that waqf property really becomes a source of funds from the community and contributes to the community. The waqf distribution model in Indonesia is still in the form of the construction of mosques, prayer rooms, schools, and other consumptive matters. The process can be developed to achieve better results, especially in the interests of improving the welfare of the Islamic Ummah. This consumptive orientation of waqf must move on to productive waqf which is widely developed in Islamic countries today.
\end{abstract}

Keywords: endowment, economy, people

\section{Pendahuluan}

Dalam ajaran Islam ada dua dimensi utama hubungan yang harus dipelihara, yaitu hubungan manusia dengan tuhan dan hubungan manusia manusia lain dalam masyarakat serta benda yang ada di alam sekitarnya. Kedua hubungan itu harus berjalan serentak. Menurut ajaran Islam, dengan melaksanakan kedua hubungan itu hidup manusia akan sejahtera baik di dunia maupun di akhirat. Untuk mencapai kesejahteraan

${ }^{1}$ Dosen Program Studi Ekonomi Syariah STAI Syaichona Moh. Cholil Bangkalan Madura. 
dimaksud, di dalam Islam ada syari'at yang mengatur hubungan manusia dengan Tuhan dan syari'at yang mengatur hubungan manusia dengan manusia lain dalam masyarakat serta benda di alam sekitarnya.

Wakaf adalah suatu lembaga Islam yang satu sisi berfungsi sebagai ibadah kepada Allah Swt, sedangkan di sisi lain wakaf juga berfungsi sosial. Wakaf merupakan implementasi iman yang mantap dan tinggi antara sesama manusia. Oleh karenanya wakaf adalah suatu lembaga Islam yang dapat dipergunakan bagi manusia untuk mewujudkan dan memelihara hubungan manusia dengan Allah Swt, dan hubungan manusia dengan manusia lain dalam masysrakat. Dalam fungsinya sebagai ibadah, ia diharapkan menjadi bekal bagi kehidupan si waqif di hari kemudian, karena ia merupakan suatu bentuk amal jariyah yang pahalanya akan terus mengalir selam harta wakaf dimanfaatkan. Hal ini sesuai dengan hadith Nabi Saw:

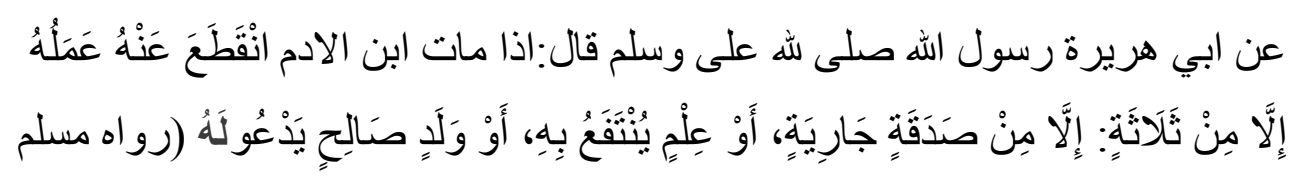

Artinya: Diriwayatkan dari Abu Hurairah bahwa Rasulullah Saw, bersabda: "Apabila anak Adam (manusia) wafat, maka terputuslah amal perbuatannya, kecuali tiga hal, yaitu: dari sedekah jariah wakaf, atau ilmu yang dimanfaatkan, atau anak sholeh yang mendoakanya.

Yang dimaksud sedekah jariyah adalah amalan yang terus bersambung manfaatnya. Seperti wakaf aktiva tetap (contoh: tanah), kitab, dan mushaf al-Qur'an. Inilah alasannya kenapa Ibnu Hajar Al-Asqalani memasukkan hadits ini dalam bahasan wakaf dalam Bulughul Maram. Karena para ulama menafsirkan sedekah jariyah dengan wakaf.

Sedangkan dari fungsi sosialnya, wakaf merupakan aset yang amat bernilai dalam pembangunan umat. Hal ini terbukti melalui perjalanan sejarah umat Islam, bahwa wakaf telah berperan sebagai sarana dan modal yang secara nyata telah memberikan sumbangan besar dari wakaf. Sebagai contoh, harta wakaf yang dimiliki oleh al-Azhar dapat menjadi modal 
utama dalam memajukan serta mengembangkan potensi sumber daya manusia dalam sumber pendidikan.

Di Indonesai wakaf telah dikenal dan dilaksanakan oleh umat Islam sejak agama Islam masuk ke Indonesia. Sebagai lembaga Islam, wakaf telah salah satu penunjang perkembangan masyarakat Islam terutama menyangkut pengembangan potensi sumber daya manusianya. Sebagian besar rumah ibadah, perguruan Islam, dan lembaga-lembaga keagamaan juga dibangun diatas tanah wakaf, walaupun dalam berbagai bentuknya, mayoritas masih dalam bentuk wakaf konsumtif yang dikelola secara tradisional. Hal ini terjadi, karena pemahaman tradisional masyarakat terhadap konsep wakaf.

\section{Pembahasan}

\section{Pengertian Wakaf}

Secara etimologi wakaf الوقف) العبس berarti المنع (menahan, mencegah) seperti dikatakan الداروحبستها في سبيل اله (له اله Dalam bahasa Arab, wakaf kadang-kadang bermakna objek atau benda yang diwakafkan (almauquf 'alaih) atau tidak dipakai dalam pengertian wakaf sebagai suatu istitusi seperti yang dipakai dalam perundang-undangan Mesir. Sedangkan di Indonesia, term wakaf dapat bermakna sebagai objek yang diwakafkan atau sebagai institusi. Namun demikian bila diperhatikan maka akan dijumpai bahwa wakaf di Indonesia lebih menonjol dalam pengertiannya sebagai objek yang diwakafkan. ${ }^{3}$

Adapun secara terminologi, terdapat beberapa pengertian yang dirumuskan oleh para ulama di antaranya:

\section{Madzhab Hanafi}

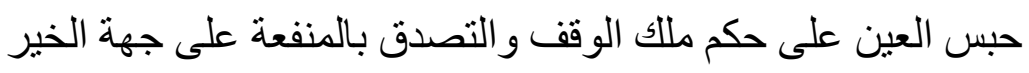

${ }^{2}$ Fuad Abd. al-Latif al-Sartawi, al-Tamwil al-Islamiy wa Daur-Qita al-Khash ( Amman: Dar al-Musayyarah,1999), 187

${ }^{3}$ Juhaya S. Praja, Perwkafan di Indonesia: Sejarah, Pemikiran, Hukum Dan Perkembangannya (Bandung Yayasan Piara1995),6 
"Menahan benda tetap atas status milik orang yang mewakafkanya dan disedekahkan manfaatnya saja untuk kepentingan yang baik". ${ }^{4}$

2. Madzhab Maliki

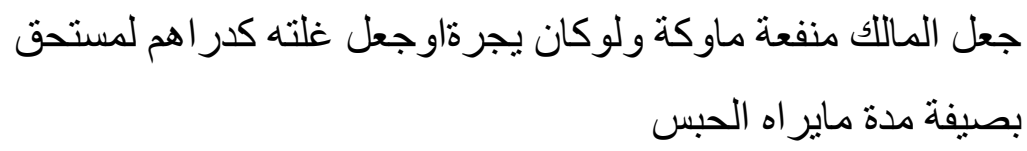

"Menjadikan manfaat benda yang dimiliki, sekalian pemiliknya sedang sewa, atau menjadikan seperti dirham untuk orang yang berhak, dengan bentuk penyerahan sesuai dengan apa yang dikehendaki oleh orang yang mewakafkannya". 5

3. Madzhab Syafi'i

$$
\text { حبس مال يكن الاتقاع التصرف فى رقبة على مصرف مباح موجود }
$$

"Menahan harta yang dapat diambil manfaatnya dengan tetap utuhnya barang, dan barang itu lepas dari penguasaan orang yang mewakafkan serta dimanfaatkan pada suatu yang diperbolehkan agama lagi ada". ${ }^{6}$

4. Madzhab Hambali

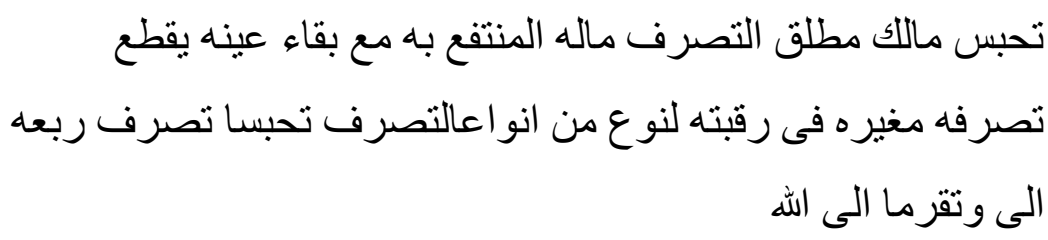

"Menahan kebebasan pemilik harta dalam membelanjakan hartanya yang bermanfaat dengan tetap utuhnya harta dan memutuskan semua hak

${ }^{4}$ Ibn Abidin, Radd al-Muhtar, (Beirut: Dar Al-Ilmiyah,tt), juz VI,518

${ }^{5}$ Wahbah al-Zuhaili, Al-Fiqih Al-Islamiyah wa Adillatuh (Beirut : Dar al-Fikr,1989), Vol. Viii, 155

${ }^{6}$ Ibn Abidin, Radd....,518 
penguasaan terhadap harta itu, sedang manfaatnya dipergunakan pada suatu kebaikan untuk mendekatkan diri kepadanya". ${ }^{7}$

Dari keempat definisi yang dikemukakan di atas, dapat diambil beberapa unsur dari wakaf yaitu:

1. Menahan suatu benda

2. Disedekahkan manfaat atau hasilnya saja

3. Untuk kebaikan sesuai ajaran Islam

Dalam hukum Islam, wakaf berarti menyerahkan suatu hak milik yang tahan lama (zatnya) kepada seseorang atau nadzir (penjaga wakaf), baik berupa perorangan atau lembaga, dengan ketentuan bahwa hasilnya digunakan sesuai dengan syariat Islam. ${ }^{8}$ Harta yang telah diwakafkan keluar dari hak milik yang mewakafkan (waqif), dan bukan pula hak milik nadzir/lembaga pengelola wakaf tapi menjadi hak milik Allah yang harus dimanfaatkan untuk kesejahteraan masyarakat. Filosofi yang terkandung dalam amalan wakaf menghendaki agar harta wakaf itu tidak boleh dipendam tanpa hasil yang dinikmati oleh mauquf alaih (pihak yang berhak menerima hasil wakaf). Makin banyak harta wakaf yang dapat dinikmati yang berhak, makin besar pula pahala yang akan mengalir ke waqif.

\section{Sumber Legitimasi Wakaf}

1. Al-Qur'an

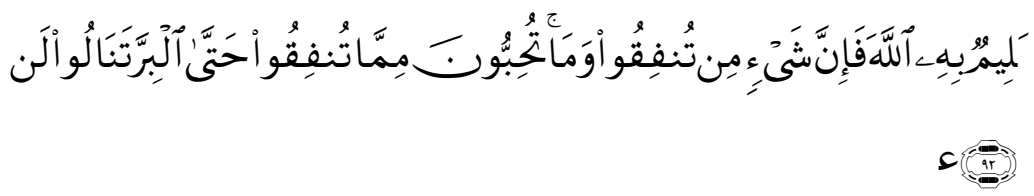

"Kamu sekali-kali tidak sampai kepada kebaktian (yang sempurna) sebelum kamu menafkahkan sebagian harta yang kamu cintai. Dan apa saja yang kamu nafkahkan, maka sesungguhnya Allah mengetahui" (Ali Imran: 92) ${ }^{9}$

\footnotetext{
${ }^{7}$ Ibid

${ }^{8}$ Msyfuk Zuhdi, Studi Islam, Muamalah, (Jakarta: Rajawali Press, 1988), jilid III, 76-77

${ }^{9}$ Universitas Islam Indonesia, Qur'an Karim dan Terjemah artinya, (Yogyakarta : UII Press, 1997),109
} 
Ayat di atas memang tidak secara tegas menyebutkan tentang wakaf, hanya mengemukakan tentang perintah menafkahkan harta yang kamu cintai untuk hal kebajikan, yang ditafsirkan para ulama dengan wakaf, karena wakaf pada dasarnya adalah menafkahkan/menginfaqkan harta untuk kebajikan.

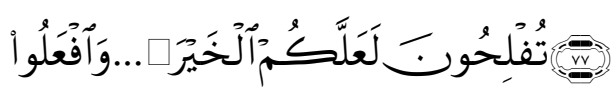

“...Dan berbuat baiklah agar kamu bahagia" (Al-Hajj :77)10

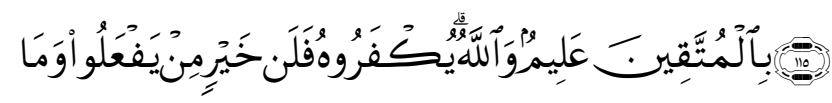

"Kebaikan apapun yang mereka lakukan, sama sekali tidak terhalang untuk menerima pahala, dan Allah Maha mengetahui orang-orang yang bertakwa" (Ali-Imron: 115) ${ }^{11}$

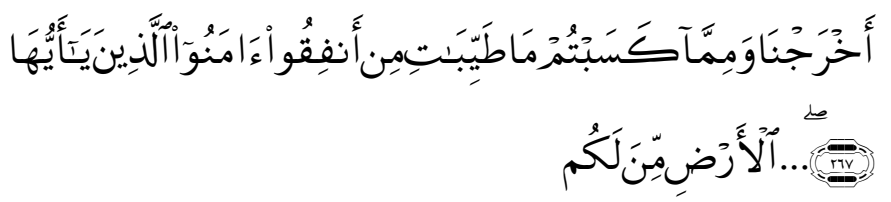

"Hai orang-orang yang beriman nafkahkanlah (di jalan Allah) sebagian hasil dari usahamu yang baik-baik dan sebagian dari apa yang kami keluarkan dari bumi untuk kamu" (Al-Baqarah : 267) ${ }^{12}$

2. Al-Sunnah

${ }^{10}$ Ibid,594

${ }^{11}$ Ibid, 115

${ }^{12} \mathrm{Ibid}, 80$ 


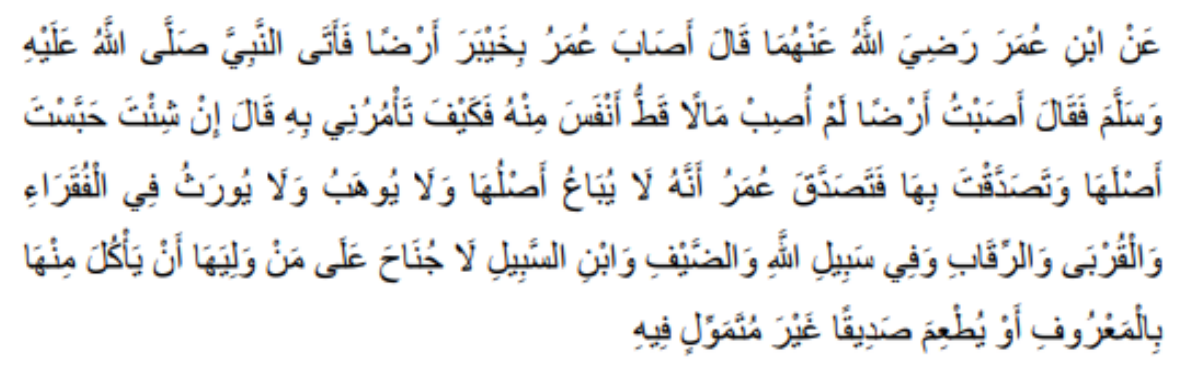

Diriwayatkan dari Ibnu 'Umar Ra, bahwa 'Umar Ibn Khattab memperoleh tanah (kebun) di Khaibar, lalu ia datang kepada Nabi Saw, seraya berkata: "Wahai Rasulullah saya memperoleh tanah yang belum pernah saya peroleh harta yang lebih baik bagiku melebihi tanah tersebut, maka apa yang engkau perintahkan (kepadaku) mengenainya?" Nabi Saw menjawab: "Jika mau, kamu tahan pokoknya dan kamu sedekahkan (hasilnya)". Ibnu 'Umar berkata: "Maka Umar menyedekahkan tanah tersebut (dengan mensyaratkan) bahwa tanah itu tidak dijual, tidak dihibahkan, dan tidak diwariskan, yaitu kepada orang-orang fakir, kerabat, riqab (hamba sahaya), sabilillah, tamu dan ibnu sabil. Tidak berdosa bagi orang yang mengelola untuk memakan dari (hasil) tanah itu secara ma'ruf (wajar) atau memberi makan seorang teman, dengan tanpa menjadikannya sebagai harta hak milik.

Menurut Al-Tirmidzi hadits ini diamalkan oleh semua ahli ilmu dari para sahabat para Nabi Saw dan orang-orang selain mereka. Kami tidak mengetahui adanya perbedaan dari seorang pun di antara orang-orang terdahulu dari mereka. Hal tersebut adalah wakaf pertama didalam Islam. ${ }^{13}$

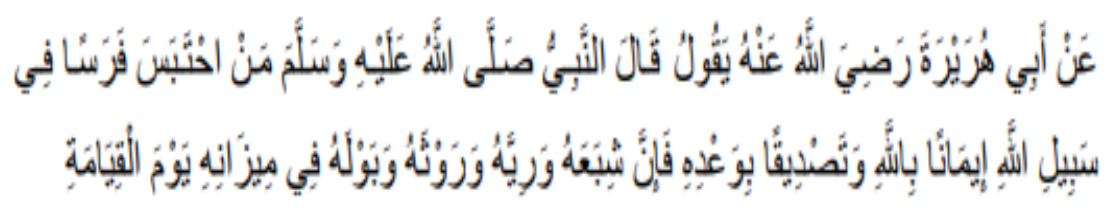

"Diriwayatkan oleh Ahmad dan Al-Bukhari dari Abu Hurairah, bahwa Rasulullah Saw bersabda: "Barang siapa menafkahkan seekor kuda

\footnotetext{
${ }^{13}$ Sayyid Sabiq, Fiqih sunnah 14, terj. Mudzakir, (Bandung : PT. Al-Maarif, 1987), 
dijalan Allah dengan penuh keimanan dan keikhlasan, maka makanannya, tahinya dan kencinya itu menjadi amal kebaikan pada timbangan di hari kiamat."

\section{Hukum Wakaf}

Sahid al-Majmu' berpendapat bahwa wakaf merupakan ibadah yang mandub, menurut ilmu Qudamah adalah mustajab, sedangkan ijma' sahabat memperbolehkan dan menetapkan wakaf, karena wakaf ini merupakan sebuah kebutuhan. Hal ini dapat dilihat dari perkataan Zaid ibn Thanit R.a: "Kita tidak melihat suatu kebaikan bagi mayit maupun orang yang masih hidup dari wakaf, dimana pahala dari wakaf tersebut akan terus mengalir bagi yang sudah meninggal, sedangkan bagi orang yang masih hidup wakaf ini tidak bisa dihibahkan diwariskan."

Adapun kebayakan ulama memperbolehkan dan mensyahkan wakaf kecuali apa yang diriwayatkan dari Abu Hanifah dan Zufar menolak dan membatalkan wakaf. Khisaf berkata: ayahku mengabarkanku dari al-Hasan ibn Ziyad bahwa Abu Hanifa berkata: wakaf itu tidak diperbolehkan kecuali adanya wakaf itu dengan jalan wasiat. Menurut Abu Hanifa bolehnya wakaf ini seperti bolehnya meminjam, yang mana harta wakaf itu ditasyarufkan manfaatnya saja dengan tetapnya zat tetap menjadi pemilik waqif. ${ }^{14}$

\section{Pengaruh Wakaf dalam Kehidupan Ekonomi}

Wakaf mengandung dua dimensi, yakni di satu sisi berfungsi sebagai ibadah dan di sisi lain sebagai sosial, jika wakaf tersebut dapat dikelola dengan baik maka akan dapart memberdayakan uamat. Karena wakaf merupakan salah satu lembaga Islam yang sangat potensial untuk lebih dikembangkan guna membantu yang kurang mampu. Menurut al-Dahlawi bahwa sesungguhnya Rasulullah Saw, mengistimbatkan hukum wakaf itu adalah kemaslahatan (umat), yang hal ini tidak ditemukan dalam bentuk shadaqah-shadaqah lain. Karena dengan wakaf, manusia telah mentasarufkan harta yang banyak di jalan Allah yang manfaatnya tidak

${ }^{14}$ Al-Sartawi, al-Tamwil..., 190-192 
punah, dan hal inilah yang dibutuhkan oleh kaum fakir. ${ }^{15}$ Sayangnya wakaf yang jumlahnya begitu banyak, pada umumnya manfaatnya masih bersifat konsumtif dan belum dikelola secara produktif. Suatau kenyataan yang dilihat bahwa wakaf yang ada di Indonesia pada umumnya masih berupa masjid, musholla, madrasah, makam, rumah yatim piatu, dan sejenisnya.

Berbeda halnya dengan yang terjadi di sebagian besar negara Islam, seperti: Mesir, Yordania, dan Saudi Arabia, walaupun wakaf merupakan lembaga Islam yang hukumnya sunnah, namun lembaga ini dapat berkembang dengan baik. Di negara- negara tersebut, bentuk wakaf tidak hanya terbatas pada benda yang tidak bergerak, tetapi juga benda bergerak, wakaf selain berupa sarana dan prasarna ibadah dan pendidikan juga berupa tanah pertanian, perkebunan, flat, uang, saham, real estate dan lain-lain. Semuanya dikelola secara produktif. Dengan demikian hasilnya benar-benar dapat dipergunakan untuk mewujudkan kesejahteraan umat.

Munculnya wakaf selain benda-benda tak bergerak tersebut karena adanya penafsiran kembali dari ajaran wakaf, di mana terjadi karena perkembangan persoalan yang makin kompleks. Hal ini akhirnya memunculkan konsep cash wakf (wakaf tunai) yang ditawarkan oleh Prof. A. Mannan, akademisi dari Bangladesh. Dalam konsep wakaf tunai tersebut, wakaf dapat menjadi sumber tunai, dengan jalan diinfaqkan dalam bentuk uang tunai. Konsep ini terdiri dari dua hal. Pertama, waqif tidak memerlukan jumlah uang yang besar seperti dibelikan tanah. Wakaf dapat diberikan satuan-satuan yang lebih kecil, misalnya di Indonesia, sebuah sertifikat wakaf yang dikeluarkan oleh sebuah lembaga wakaf resmi, dapat dibayar menurut satuan $\operatorname{Rp} 5.000,00$ umpamanya. Selanjutnya memungkinkan memperluas jumlah waqif. Kedua, bentuk wakaf bisa berwujud harta lancar yang penggunaanya sangat fleksibel, sehingga harta wakaf bisa menjadi modal finansial yang disimpan di bank-bank atau lembaga keuangan. Wakaf juga bisa berbentuk saham perusahaan. Jadi pengusaha bisa mengalokasikan sebagian sahamnya sebagai harta wakaf yang hasilnya (deviden) dapat digunakan untuk kemaslahatan.

${ }^{15}$ Ibid, 195 
Mengenai wakaf uang ini, terdapat perbedaan dalam hukumnya. AlZuhri (wafat tahun $124 \mathrm{H}$ ) berpendapat boleh mewakafkan dinar dan dirham. Caranya ialah menjadikan dinar dan dirham tersebut modal usaha (dagang), kemudian meyalurkan keuntunganya sebagai wakaf. ${ }^{16} \mathrm{Hal}$ ini pernah dilaksanakannya untuk pembangunan sarana dakwah, sosial, dan pendidikan umat Islam. Dikisahkan, beliau mewakafkan 1000 dinar $^{17}$ kepada seorang pengusaha dan labanya diperguanakan untuk kepentingan sosial. Si pengusaha tadi tidak diperkenankan sedikitpun mengurangi modal tadi, karena dana itu merupakan dana abadi. Tugas dia adalah mengelola dan menyalurkan keuntungannya kepada yang berhak. ${ }^{18}$

Al-Zuhaili menyebutkan bahwa madzhab Hanafi juga memperbolehkannya sebagai pengecualian karena banyak dilakukan masyarakat. Sesuai yang diriwayatkan Abdullah Ibn Mas'ud yang berbunyi:

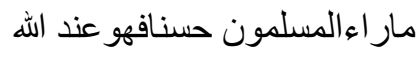

"Apa yang dipandang kaum muslimin baik, maka menurut Allah juga baik"

Menurut madzhab Hanafi bahwa hukum yang ditetapkan oleh urf (adat kebiasaan) mempunyai kekuatan hukum yang sama dengan yang ditetapkan oleh nash (teks). Cara mewakafkannya ialah menjadikan modal usaha dengan cara mudharabah atau mubadha'ah, keuntunganya disedekahkan kepada pihak wakaf.

Sebenarnya perhatian penuh terhadap pengelola wakaf ini telah ada sejak daulah umayyahya itu dengan terbentuknya diwan-diwan yang khusus menangani wakaf. Pada daulah Abbasiyah telah dibangun kantor wakaf dan diangkat seorang kepala yang dinamakan "صدر الوقف". Adapun pada daulah Usthmaniyah telah dibuat undang-undang khusus tentang

${ }^{16} \mathrm{Abu}$ al-Su'ud Muhammad, Risalah ft Jawaz waqf al-Nuqud, (Beirut : Dar Ibn Hazm,tt) 20-21

${ }^{17}$ Wahbah al-Zuhayli, Fiqh al-Islamiyah wa Adillatuh, vol. 1,248

${ }^{18}$ Abu al-Su'ud Muhammad, Risalah...,20-21 
wakaf yang berisi: Pertama, tata cara menghasilkan harta wakaf. Kedua tata cara menghasilkan harta wakaf ke sektor-sektor kebaikan. ${ }^{19}$

Perhatian yang dilakukan oleh daulah-daulah dalam pengelolahan wakaf tersebut merupakan indikasi bahwa wakaf tersebut mempunyai pengaruh yang besar terhadap kehidupan dan peraturan ekonomi yang tidak mungkin ditemukan dalam syari'at (undang-undang) lain selain Islam. Karena dalam wakaf Islam terkandung berbagai macam kebaikan.

Oleh karena itu merupakan tantangan bagi kita umat Islam untuk dapat mengelola harta wakaf dengan baik sebagai salah satu alternatif untuk mensejahterakan umat. Salah satu cara adalah mengembangkan dengan cara produktif, seperti wakaf uang dan wakaf saham.

\section{Penutup}

Wakaf telah mengakar dan menjadi tradisi umat Islam di berbagai negara. Wakaf menjadi salah satu penopang utama perkembangan masyarakat Islam, karena sebagian besar rumah ibadah, perguruan Islam dan lembaga-lembaga keagaman Islam lainnya di bangun di atas tanah wakaf.

Lembaga wakaf yang merupakan sumber aset dapat memberikan manfaat sepanjang masa. Namun pengumpulan, pengelolaan dan pendayagunaan harta wakaf secara produktif di Indonesia masih sedikit dan ketinggalan dibandingkan negara lain. Begitupun studi perwakafan di Indonesia masih terfokus pada segi hukum fikih an sich, dan belum menyentuh pada manajemen perwakafan. Padahal seharusnya wakaf dapat dikelola secara produktif dan memberikan hasil pada masyarakat, sehingga harta wakaf benar-benar menjadi sumber dana dari masyarakat dan memberikan kontribusi kepada masyarakat.

Model distribusi wakaf di Indonesia masih berupa pembangunan masjid, musholla, sekolah, dan hal-hal konsumtif lainnya. Esesnsinya dapat dikembangkan untuk mencapai hasil yang lebih baik, terutama untuk kepentingan peningkatan kesejahteraan ummat Islam. Orientasi wakaf yang konsumtif ini, harus beralih pada wakaf produktif yang banyak dikembangkan di negara-negara Islam dewasa ini.

${ }^{19}$ Al-Satawi, al-Tanwil....,194-195 


\section{DAFTAR PUSTAKA}

Al-Sartawi, Fuad Abd. 1999. Al-Latif, Al-Tanwil al-IslamiywaDaurQita alKhash, Amman: Dar al-Musayyarah.

Al-Zuhaili, Wahbah. 1989. Al-Figh Al-Islamiyahwa Adillatuh, Vol I. Beirut: Dar al-Fikr.

Al-Zuhaili, Wahbah. 1989. Al-figh Al-Islamiyahwa Adillatuh, Vol VIII. Beirut: Dar al-Fikr.

Hasanah, Uswatun. 2002. Manajemen Kelembagaan Wakaf dalam Perkembangan Wakaf. Makalah Workshop Pemberdayaan Ekonomi Umat Melalui Wakaf Produktif. The International Institute Of Islamic Thaughat Bekerjasama dengan Ditjen Bimas Islam dan Penyelenggaraan Haji Depag RI di Batam Tanggal 7-8 Januari 2002

IbnAbidin, tt. Radd al-Muhtar Juz VI. Beirut: Dar al-Kutub al-Ilmiyah.

Juhaya, S. Praja. 1995. Perwakafan di Indonesia: Sejarah, Pemikiran, Hukum Dan Perkembangannya. Bandung: Yayasan Piara.

Muhammad, Abu al-Su'ud. Tt. Risalah fi jawaz waqaf al-Nuqud. Beirut: Dar Ibn Hazm.

Raharjo, Dawam. Pengorganisasian Lembaga Wakaf dalam Pempedayaan Ekonomi Umat, Makalah Workshop Tentang Pemberdayaan Ekonomi Umat Melalui Wakaf Produktif.

Sahiq, Sayyid. 1987. Fikih Sunnah 14. Terj. Mudzakir, Bandung: Al-Maarif.

Zuhdi, Masyfuk. 1988. Study Islam, Muamalah. Jakarta: Rajawali Press. 